\title{
Article \\ Experience with Cutaneous Manifestations in COVID-19 Patients during the Pandemic
}

\author{
Alba Navarro-Bielsa ${ }^{1,2, *,+}+\mathbb{D}$, Isabel Abadías-Granado ${ }^{1,2,+} \mathbb{D}$, Ana María Morales-Callaghan ${ }^{1,2}$, \\ Catalina Suso-Estívalez ${ }^{3}(\mathbb{D})$, Marina Povar-Echeverría ${ }^{3}(\mathbb{D})$, Luis Rello ${ }^{4}$ and Yolanda Gilaberte ${ }^{1,2}$ (D) \\ 1 Dermatology Service, Hospital Universitario Miguel Servet, 50009 Zaragoza, Spain; \\ isabel.abadiasg@gmail.com (I.A.-G.); ammorales@salud.aragon.es (A.M.M.-C.); \\ ygilaberte@salud.aragon.es (Y.G.) \\ 2 IIS Aragón, Universidad de Zaragoza, 50009 Zaragoza, Spain \\ 3 Internal Medicine Service, Hospital Universitario Miguel Servet, 50009 Zaragoza, Spain; \\ catisuso@gmail.com (C.S.-E.); marinapovar89@hotmail.com (M.P.-E.) \\ 4 Biochemistry Service, Hospital Universitario Miguel Servet, 50009 Zaragoza, Spain; luisrello@gmail.com \\ * Correspondence: albanavarrobielsa@hotmail.com \\ + These authors contributed equally to this work.
}

Citation: Navarro-Bielsa, A.;

Abadías-Granado, I.

Morales-Callaghan, A.M.; Suso-Estívalez, C.; Povar-Echeverría, M.; Rello, L.; Gilaberte, Y. Experience with Cutaneous Manifestations in COVID-19 Patients during the Pandemic. J. Clin. Med. 2022, 11, 600. https://doi.org/10.3390/jcm 11030600

Academic Editor: Masutaka Furue

Received: 25 December 2021

Accepted: 21 January 2022

Published: 25 January 2022

Publisher's Note: MDPI stays neutral with regard to jurisdictional claims in published maps and institutional affiliations.

Copyright: (C) 2022 by the authors. Licensee MDPI, Basel, Switzerland. This article is an open access article distributed under the terms and conditions of the Creative Commons Attribution (CC BY) license (https:// creativecommons.org/licenses/by/ $4.0 /)$

\begin{abstract}
After the beginning of the SARS-CoV-2 pandemic, our dermatology department created a multidisciplinary unit to manage patients with cutaneous manifestations associated with COVID-19. With the objective of identifying skin lesions in patients with suspected COVID-19 and evaluating possible associations with systemic involvement, other infectious agents and coagulation disorders, we carried out a prospective observational study that included all patients that attended our COVID-19 dermatology clinic with a multidisciplinary protocol. A total of 63 patients (mean 34.6 years) were enrolled between May 2020 and February 2021. Overall, 27 patients (42.9\%) had a positive COVID-19 test, and $74.6 \%$ had COVID-19 clinical signs. The most common skin lesion was maculopapular rash $(36.5 \%)$, predominantly seen in male $(54.2 \%)$ and older patients (42 vs. 30 years), followed by chilblain-like lesions (20.6\%) in younger patients (13.9 vs. 20.9 years) who were predominantly barefoot at home $(69.2 \%)$; these patients exhibited a tendency towards a negative COVID-19 test. A total of 12 patients (19.1\%) had positive serology for herpesvirus 6 (IgM or IgG). We conclude that the COVID-19-associated skin lesions we observed were similar to those previously described. Questions as to the underlying mechanisms remain. Interferon, possibly aided by cold exposure, may cause perniosis-like lesions. Other cutaneous manifestations were similar to those caused by other viruses, suggesting that SARS-CoV-2 may reactivate or facilitate other viral infections.
\end{abstract}

Keywords: COVID-19; cutaneous manifestations; dermatology

\section{Introduction}

Throughout the recent coronavirus disease 2019 (COVID-19) pandemic, several publications warned of possible cutaneous manifestations associated with this novel coronavirus (SARS-CoV-2). Galván Casas et al. [1] described the following five cutaneous clinical patterns in SARS-CoV-2 patients: acral areas of erythema with vesicles or pustules (pseudochilblain), other vesicular eruptions, urticarial lesions, maculopapular eruptions, and livedo or necrosis. Since then, dermatologists have reported multiple cases of patients with cutaneous clinical signs associated with COVID-19, requiring rapid scheduling of specific consultations carried out in a manner safe for all involved. In our hospital, we created a multidisciplinary unit with a specific protocol for patients with these cutaneous lesions.

The main objective of the present study was to investigate epidemiological, clinical, analytical, and microbiological factors associated with the different cutaneous manifestations of COVID-19. The secondary objective was to describe the frequency of the different cutaneous patterns observed in COVID-19 patients throughout the pandemic. 


\section{Participants and Methods}

\subsection{Study Population}

An observational prospective study of patients with clinically suspected and/or microbiologically diagnosed COVID-19 and skin lesions was conducted between 1 May 2020 and 17 February 2021. A specific consultation service was created in the Department of Dermatology of the Miguel Servet University Hospital (Zaragoza, Spain) in order to attend patients referred from primary care and emergency departments, in addition to hospitalized patients and health workers. After evaluation, patients were invited to participate in the study, for which written informed consent was required.

The following inclusion criteria, similar to previous reports [1], were applied: patients of any age with clinically suspected and/or microbiologically confirmed SARS-Cov2 infection, with recent skin rash (onset within the last 4 weeks). In patients aged $<18$ years, parents were required to provide informed consent and complete a questionnaire. Patients unable to complete the questionnaire or who refused to undergo a dermatological examination were excluded from the study population.

\subsection{Questionnaire and Physical Examination}

A multidisciplinary protocol was developed, including clinical assessment and completion of two questionnaires (initial consultation and after 4 weeks of follow-up. Supplementary Material: Figure S1) and a skin biopsy, if necessary. Two specific analytical profiles were created, depending on the type of cutaneous lesions: both included serology for other viruses (human herpesvirus 6 and parvovirus B19 in all cases and varicella zoster virus (VZV), syphilis, cytomegalovirus, and Epstein-Barr virus depending on the clinical manifestations), a general biochemical workup (ferritin, C-reactive protein, liver and kidney profile, vitamin D, D-dimer), and a hemogram; while the second, which was applied to patients with chilblain-like and necrotic/livedoid patterns, included an additional coagulation profile (prothrombin activity, lupus anticoagulant, anticardiolipin, anti- $\beta 2$-glycoprotein, antithrombin III, protein C, protein $S$, and homocysteine).

\subsection{Statistical Analyses}

Qualitative variables are presented as proportions and quantitative variables as measures of central tendency (mean or median) and dispersion (standard deviation or percentiles), depending on the results of the Kolmogorov-Smirnov test.

Qualitative variables were compared using Pearson's Chi-squared test, and the relationship between quantitative variables was compared using the Pearson or Spearman correlation. Comparison of qualitative and quantitative variables was conducted using the Student's T-test or Mann-Whitney U-test for variables with two categories, and ANOVA or the Kruskal-Wallis test for variables with more than two categories. Parametric or nonparametric statistical tests were used as appropriate after assessing data distribution. Logistic regression was used to identify variables associated with different cutaneous manifestations. Crude odds ratios (OR) and 95\% confidence intervals (CI95\%) were estimated. The threshold for statistical significance was set at $p<0.05$. Analyses were conducted using SPSS version 23.0 (IBM, Armonk, NY, USA).

\subsection{Ethical Concerns}

This study was strictly observational and the protocol was approved by the Aragón Ethical Committee for Clinical Research (CP-CI PI20/323).

\section{Results}

The characteristics of the study population are presented in Table 1 . The cohort included 63 patients (61.9\% female), with a mean (SD) age of $34.6 \pm 21.8$ years (range, 0.5-74 years). Overall, 24 patients (38.1\%) exercised regularly; 16 (25.4\%) had been exposed to the sun during the month preceding lesion appearance; 21 (33.3\%) were usually barefoot at home; and 9 (14.3\%) were smokers (5 smoked more than 10 cigarettes/day). For all 
analytical variables, the mean was within the normal range of our laboratory, with the exception of vitamin D levels, for which the mean (SD) value was below the normal range $(67.7(26.9) \mathrm{nmol} / \mathrm{L})$. Serology for other viruses indicated the presence of IgM and/or IgG seroconversion to HHV-6 in 12 of the 63 patients (mean age, 30 (3-50)). The remaining 51 patients were negative for HHV-6 IgM. Of these 12 patients, only 4 (33\%) tested positive for SARS-CoV-2. Results of tests for all other viruses were negative or consistent with past infection.

Table 1. Epidemiological, analytical, and microbiological characteristics of patients with COVID-19associated cutaneous lesions.

\begin{tabular}{|c|c|c|}
\hline Variable & & \\
\hline Age, mean $\pm S D$ (range) & & $34.6 \pm 21.8(0.5-74)$ \\
\hline \multirow[t]{2}{*}{$\operatorname{Sex} n(\%)$} & Male & $24(38.1)$ \\
\hline & Female & $39(61.9)$ \\
\hline Exercise $n(\%)$ & & $24(38.1)$ \\
\hline Sun exposure $n(\%)$ & & $16(25.4)$ \\
\hline Barefoot at home $n(\%)$ & & $21(33.3)$ \\
\hline Smokers $n(\%)$ & & $9(14.3)$ \\
\hline Glucose $(\mathrm{mg} / \mathrm{dL})$, mean $\pm S D$ (range) & & $90.55 \pm 12.5(68-135)$ \\
\hline Urea $(\mathrm{mg} / \mathrm{dL})$, mean $\pm S D$ (range) & & $33 \pm 8.4(18-57)$ \\
\hline GOT (IU/L), mean $\pm S D$ (range) & & $27.2 \pm 18.2(15-152)$ \\
\hline GPT (IU/L), mean $\pm S D$ (range) & & $27.8 \pm 46.2(6-361)$ \\
\hline GGT (IU/L), mean $\pm S D$ (range) & & $24.1 \pm 23.6(7-156)$ \\
\hline LDH (IU/L), mean $\pm S D$ (range) & & $195.2 \pm 51.9(106-363)$ \\
\hline $\mathrm{CRP}(\mathrm{mg} / \mathrm{dL})$, mean $\pm S D($ range $)$ & & $0.29 \pm 0.5(0.02-3.56)$ \\
\hline Ferritin (ng/dL), mean $\pm S D$ (range) & & $99 \pm 105.4(10.7-553.9)$ \\
\hline Vitamin D (nmol/L), mean $\pm S D$ (range) & & $67.7 \pm 26.9(17.9-172.1)$ \\
\hline Hemoglobin $(\mathrm{g} / \mathrm{dL})$, mean $\pm S D$ (range) & & $13.9 \pm 1,3(10.1-16.8)$ \\
\hline Leucocytes mean $\pm S D$ (range) & & $7149.1 \pm 2619.7(2500-16,300)$ \\
\hline Lymphocytes mean $\pm S D$ (range) & & $2705.1 \pm 1474.5(900-11,399)$ \\
\hline Platelets mean $\pm S D$ (range) & & $258,051 \pm 76,546(133,000-448,000)$ \\
\hline D-dimer $(\mathrm{ng} / \mathrm{mL})$, mean $\pm S D$ (range) & & $401.4 \pm 443.9(80-3066)$ \\
\hline \multirow[t]{3}{*}{ Human herpesvirus $6 n(\%)$} & Negative & $15(23.8)$ \\
\hline & IgG & $36(57.1)$ \\
\hline & $\operatorname{Ig} M$ & $12(19)$ \\
\hline \multirow[t]{2}{*}{ Parvovirus B19 $n(\%)$} & Negative & $44(69.8)$ \\
\hline & $\operatorname{IgG}$ & $19(30.2)$ \\
\hline
\end{tabular}

Abbreviations: GOT, glutamic oxaloacetic transaminase; GPT, glutamic pyruvic transaminase; GGT, gammaglutamyl transpeptidase; $\mathrm{LDH}$, lactate dehydrogenase; CRP, C-reactive protein.

\subsection{COVID-19 Clinical Signs}

Most patients (74.6\%) had clinical signs suggestive of COVID-19 (Table 2). The most frequent sign was fever (55.6\%), followed by general malaise and/or asthenia (44.4\%), headache $(34.9 \%)$, digestive signs (vomiting, diarrhea, and/or abdominal pain) (28.6\%), cough (28.6\%), dyspnea (25.4\%), and anosmia and/or dysgeusia (22.2\%). Despite the high prevalence of these signs, only $42.9 \%$ had a positive COVID-19 test result (nasopharyngeal smear + PCR, 23; IgG serology, 22; IgM serology, 9), and 30 patients (47.6\%) had been exposed to an individual diagnosed with COVID-19 or with suggestive signs. 
Table 2. Clinical and microbiological findings in patients with cutaneous lesions related to COVID-19 infection.

\begin{tabular}{cc}
\hline Variable & $\boldsymbol{n} \mathbf{( \% )}$ \\
\hline COVID-19 exposure & $30(47.6)$ \\
Positive COVID-19 test & $27(42.9)$ \\
Nasopharyngeal smear + PCR & $23(36.8)$ \\
IgG serology & $22(35.2)$ \\
IgM serology & $9(14.4)$ \\
COVID-19 symptoms & $47(74.6)$ \\
Fever & $35(55.6)$ \\
General malaise/asthenia & $28(44.4)$ \\
Headache & $22(34.9)$ \\
Digestive signs & $18(28.6)$ \\
Cough & $18(28.6)$ \\
Dyspnea & $16(25.4)$ \\
Anosmia & $14(22.2)$ \\
\hline
\end{tabular}

\subsection{COVID-19 Cutaneous Manifestations}

The cutaneous manifestations of the cohort are summarized in Table 3. The most common were maculopapular eruptions $(38.1 \%)$, followed by acral areas of erythema with vesicles or pustules (pseudo-chilblain) $(20.6 \%)$, vesicular eruptions $(12.7 \%)$, urticarial lesions $(9.5 \%)$, and livedo or necrosis $(7.9 \%)$. In patients with maculopapular eruptions, the most common pattern was morbilliform, followed by pityriasis rosea-like and eczematous, with toxicoderma suspected in 3 patients. Cutaneous signs were detected in $68.9 \%$ of participants, the most common of which were pruritus, followed by stinging and pain. None of the participants reported photosensitivity.

Table 3. Characteristics of cutaneous lesions associated with COVID-19.

\begin{tabular}{cc}
\hline Variable & $\boldsymbol{n} \mathbf{( \% )}$ \\
\hline Maculopapular & $24(38.1)$ \\
Morbilliform & $7(29.1)$ \\
Pityriasis rosea & $5(20.8)$ \\
Eczematous & $4(16.6)$ \\
Other & $8(33.3)$ \\
Pseudo-chilblain & $13(20.6)$ \\
Vesicular & $8(12.7)$ \\
Urticarial & $6(9.5)$ \\
Livedo/necrosis & $5(7.9)$ \\
Cutaneous signs & $43(68.3)$ \\
Pruritus & $32(74.4)$ \\
Stinging & $9(20.9)$ \\
Pain & $7(16.2)$ \\
Treatment & $41(65.1)$ \\
Topical corticosteroids & $28(44.4)$ \\
Oral antihistamines & $16(25.4)$ \\
Oral corticosteroids & $10(15.9)$ \\
Clinical skin improvement & \\
Complete & $33(52.4)$ \\
Partial & $22(34.9)$ \\
Null & $5(7.9)$ \\
Age, Mean ( \pm SD) & \\
Maculopapular & $42(21.7)$ \\
Pseudo-chilblain & $13.9(9.3)$ \\
Vesicular & $39.6(22.5)$ \\
Urticarial & $50.5(21.8)$ \\
Livedo/necrosis & $29.1(11.6)$ \\
\hline
\end{tabular}


A total of $65 \%$ of participants received treatment, most with topical corticosteroids $(44.4 \%)$, followed by oral antihistamines (25.4\%) and oral corticosteroids $(15.4 \%)$. After 1 month of follow-up, the cutaneous lesions had completely resolved in $52.4 \%$ of the patients, partially improved in $34.9 \%$, and remained unchanged in $7.9 \%$.

A total of 9 biopsies were performed, 6 in patients with maculopapular eruption, 2 with livedo and 1 with vesicular eruption; the most frequent pattern was a vacuolar and/or lichenoid superficial perivascular dermatitis, accompanied by epidermal hyperplasia consistent with drug/viral exanthematous dermatitis; dermatitis with minimal changes such as mild edema in the dermis and dilation/ectasia of superficial plexus capillaries in the livedoid pattern; and epidermal necrosis with reepithelialization probably due to subepidermal blister consistent with erythema multiforme in vesicular eruption.

The number of consultations decreased throughout the course of the pandemic (Supplementary Material: Table S1). In Aragon, 4 waves occurred during the study period. As shown in Figure 1, the frequency of the different types of dermatosis associated with COVID-19 changed with each wave, although the maculo-papular pattern was the most common in all cases. In the second wave (July-August 2020), the vesicular pattern was the second most frequent, whereas the pseudo-chilblain pattern was more frequent in the first wave (March-April 2020). Other types of cutaneous manifestations not described during the first wave [2] became more common as the pandemic progressed, especially recurrent chilblains and persistent skin manifestations, with a positive lupus anticoagulant test observed in 2 patients with post-COVID syndrome and telogen effluvia observed in 2 cases with an earlier onset than classic telogen effluvia, 2 and 4 months after the COVID-19 disease, in agreement with Rossi et al.'s description [3].

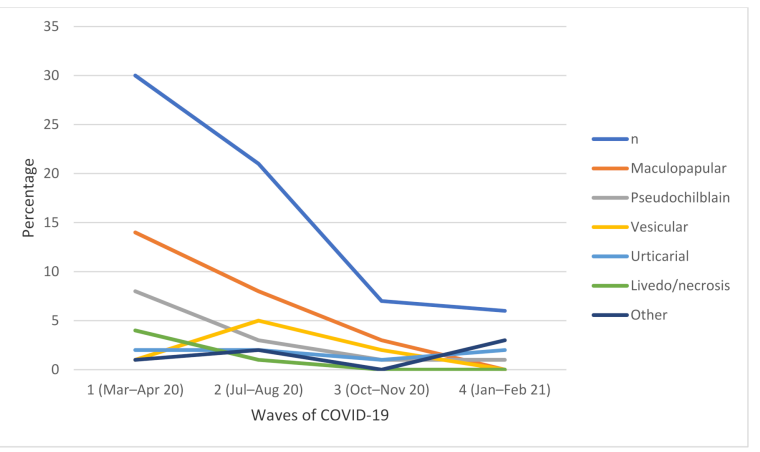

Figure 1. Evolution of the incidence of cutaneous lesions associated with COVID-19 over the 4 waves of the pandemic.

\subsection{Bivariable and Multivariable Analysis}

Table 4 shows the bivariable analysis performed to identify variables associated with any of the different cutaneous patterns. All variables for which the bivariable analysis revealed a significant association were included in the multivariate analysis.

The multivariate analysis revealed that patients with maculopapular eruptions were predominantly male (54.2\% vs. $28.2 \%$ female; $p=0.03$; OR 0.02 ; CI95\% 1.23-18.35), were not barefoot at home (20 vs. $4 ; p=0.02$; OR 0.04; CI95\% 0.31-0.94), and showed a trend towards older age (42 vs. 30 years; $p=0.04$; OR 0.16; CI95\% 0.99-1.06). Moreover, higher levels of glucose (93.8 vs. $87.7 \mathrm{~g} / \mathrm{L} ; p=0.01)$ and GGT (29.3 vs. $20.8 \mathrm{U} / \mathrm{L} ; p=0.03$ ) were recorded in these patients (Nagelkerke $\mathrm{R}^{2}=0.343$; Hosmer-Lemeshow test, $p=0.208$ ). 
Table 4. Bivariable analysis performed to identify variables associated with any of the different cutaneous patterns.

\begin{tabular}{|c|c|c|c|c|c|c|c|c|c|c|c|c|c|c|c|c|}
\hline \multirow[t]{2}{*}{ Variable } & & \multicolumn{2}{|c|}{ Maculopapular } & \multirow[t]{2}{*}{$p$-Value } & \multicolumn{2}{|c|}{ Pseudochilblain } & \multirow[t]{2}{*}{$p$-Value } & \multicolumn{2}{|c|}{ Vesicular } & \multirow[t]{2}{*}{$p$-Value } & \multicolumn{2}{|c|}{ Urticarial } & \multirow[t]{2}{*}{$p$-Value } & \multicolumn{2}{|c|}{ Livedo/Necrosis } & \multirow[t]{2}{*}{$p$-Value } \\
\hline & & No & Yes & & No & Yes & & No & Yes & & No & Yes & & No & Yes & \\
\hline \multirow{3}{*}{$\begin{array}{c}\text { Mean age } \\
\text { (SD) [range] } \\
\text { Sex }\end{array}$} & $\begin{array}{c}34.6(21.8) \\
{[0.5-74]}\end{array}$ & $\begin{array}{l}30(20.8) \\
{[0.6-73]}\end{array}$ & $\begin{array}{c}42(21.7) \\
{[2.7-74.5]}\end{array}$ & 0.041 & $\begin{array}{c}40(20.9) \\
{[2.7-74.5]}\end{array}$ & $\begin{array}{l}13.9(9.3) \\
{[0.6-34]}\end{array}$ & 0.000 & & & 0.508 & & & 0.421 & & & 0.648 \\
\hline & Male & $11(45.8)$ & $13(54.2)$ & \multirow{2}{*}{0.039} & & & \multicolumn{3}{|l|}{0.976} & 0.111 & & & \multicolumn{3}{|l|}{0.528} & 0.068 \\
\hline & Female & $28(71.8)$ & $11(28.2)$ & & & & & & & & & & & & & \\
\hline \multirow{3}{*}{$\begin{array}{l}\text { Exercise } \\
\text { Barefoot }\end{array}$} & & & & \multicolumn{3}{|l|}{0.939} & 0.541 & & & 0.970 & & & \multicolumn{3}{|l|}{0.528} & 0.927 \\
\hline & No & $22(52.4)$ & 20 (47.6) & \multirow{2}{*}{0.028} & $38(90.5)$ & $4(9.5)$ & \multirow{2}{*}{0.002} & & & 0.789 & & & \multirow[t]{2}{*}{1} & & & 0.742 \\
\hline & Yes & $17(81)$ & $4(19)$ & & $12(57.1)$ & $9(42.9)$ & & & & & & & & & & \\
\hline Smoker & No & & & 0.702 & & & 0.095 & & & 0.862 & & & 0.875 & $\begin{array}{c}51 \\
(96.2)\end{array}$ & $2(3.8)$ & 0.037 \\
\hline $\begin{array}{l}\text { Number of } \\
\text { cigarettes }\end{array}$ & & & & 0.872 & & & 0.255 & & & 0.528 & & & 0.440 & & & 0.151 \\
\hline $\begin{array}{l}\text { Sun previous } \\
\text { days }\end{array}$ & & & & 0.590 & & & 0.829 & & & 0.978 & & & 0.133 & & & 0.434 \\
\hline $\begin{array}{l}\text { Cutaneous } \\
\text { signs }\end{array}$ & & & & 0.185 & & & 0.451 & & & 0.211 & & & 0.404 & & & 0.157 \\
\hline - Pruritus & No & & & 0.674 & & & 0.318 & $30(96.8)$ & $1(3.2)$ & 0.026 & & & 0.094 & $\begin{array}{c}26 \\
(83.9)\end{array}$ & $\begin{array}{c}5 \\
(16.1) \\
\end{array}$ & 0.018 \\
\hline & Yes & & & & & & & $25(78.1)$ & $7(21.9)$ & & & & & $32(100)$ & $0(0)$ & \\
\hline - Stinging & No & & & 0.715 & & & 0.309 & $49(90.7)$ & $5(9.3)$ & 0.045 & & & 0.293 & & & 0.341 \\
\hline & Yes & & & & & & & $6(66.7)$ & $3(33.3)$ & & & & & & & \\
\hline & Yes & $7(100)$ & $0(0)$ & 0.028 & $3(42.9)$ & $4(57.1)$ & 0.011 & & & 0.285 & & & & 5 (71.4) & $\begin{array}{c}2 \\
(28.6) \\
\end{array}$ & 0.032 \\
\hline $\begin{array}{l}\text { COVID-19 } \\
\text { symptoms }\end{array}$ & & & & 0.256 & & & 0.617 & & & 0.978 & & & 0.133 & & & 0.733 \\
\hline - Fever & & & & 0.223 & & & 0.889 & & & 0.672 & & & 0.249 & & & 0.252 \\
\hline - Cough & & & & 0.512 & & & 0.844 & & & 0.550 & & & 0.497 & & & 0.658 \\
\hline - Dyspnea & & & & 0.590 & & & 0.829 & & & 0.978 & & & 0.606 & & & 0.773 \\
\hline - Myalgia & No & & & 0.223 & 24 (68.6) & 11 (31.4) & 0.018 & & & 0.735 & 34 (97.1) & $1(2.9)$ & 0.044 & $\begin{array}{c}30 \\
(85.7) \\
\end{array}$ & $\begin{array}{c}5 \\
(14.3) \\
\end{array}$ & 0.037 \\
\hline & Yes & & & & $26(92.9)$ & $2(7.1)$ & & & & & $23(82.1)$ & $5(17.9)$ & & $28(100)$ & $0(0)$ & \\
\hline $\begin{array}{l}\text { - Digestive } \\
\text { signs }\end{array}$ & & & & 0.935 & & & 0.623 & & & 0.811 & & & 0.786 & & & 0.658 \\
\hline - Headache & & & & 0.568 & & & 0.541 & & & 0.948 & & & 0.914 & & & 0.405 \\
\hline - Anosmia & & & & 0.405 & & & 0.157 & & & 0.266 & & & 0.085 & & & 0.213 \\
\hline $\begin{array}{l}\text { Improvement } \\
\text { in cutaneous } \\
\text { signs on } \\
\text { second zisit }\end{array}$ & No & & & 0.904 & & & 0.863 & & & 0.687 & & & 0.324 & $\begin{array}{c}28 \\
(84.4)\end{array}$ & $\begin{array}{c}5 \\
(15.2)\end{array}$ & 0.035 \\
\hline & Yes & & & & & & & & & & & & & $27(100)$ & $0(0)$ & \\
\hline
\end{tabular}


Table 4. Cont.

\begin{tabular}{|c|c|c|c|c|c|c|c|c|c|c|c|c|c|c|c|c|}
\hline \multirow{2}{*}{$\begin{array}{c}\text { Variable } \\
\text { Positive } \\
\text { COVID-19 } \\
\text { test }\end{array}$} & \multirow[b]{2}{*}{ No } & \multicolumn{2}{|c|}{ Maculopapular } & \multirow{2}{*}{$\begin{array}{c}p \text {-Value } \\
0.525\end{array}$} & \multicolumn{2}{|c|}{ Pseudochilblain } & \multirow{3}{*}{$\begin{array}{c}p \text {-Value } \\
0.015\end{array}$} & \multicolumn{2}{|c|}{ Vesicular } & \multirow{2}{*}{$\begin{array}{c}p \text {-Value } \\
0.135\end{array}$} & \multicolumn{2}{|c|}{ Urticarial } & \multirow{2}{*}{$\begin{array}{c}p \text {-Value } \\
0.261\end{array}$} & \multicolumn{2}{|c|}{ Livedo/Necrosis } & \multirow{3}{*}{$\begin{array}{c}p \text {-Value } \\
0.035\end{array}$} \\
\hline & & & & & $22(66.7)$ & $11(33.3)$ & & & & & & & & $\begin{array}{c}28 \\
(84.8)\end{array}$ & $\begin{array}{c}5 \\
(15.2)\end{array}$ & \\
\hline & Yes & & & & $25(92.6)$ & $2(7.4)$ & & & & & & & & $27(100)$ & $0(0)$ & \\
\hline Glucose & $\begin{array}{c}90.55(12.5) \\
{[68-135]}\end{array}$ & $\begin{array}{c}87.7 \\
(12.9) \\
{[68-135]}\end{array}$ & $\begin{array}{c}93.8(10.8) \\
{[77-124]}\end{array}$ & 0.014 & $\begin{array}{c}93(12) \\
{[74-135]}\end{array}$ & $\begin{array}{l}82(7.8) \\
{[68-96]}\end{array}$ & 0.001 & & & 0.162 & & & 0.517 & & & 0.162 \\
\hline Urea & $\begin{array}{l}33(8.4) \\
{[18-57]}\end{array}$ & & & 0.263 & & & 0.069 & $\begin{array}{l}31.3(9) \\
{[0.2-50]}\end{array}$ & $\begin{array}{c}41.4(8.3) \\
{[31-57]} \\
\end{array}$ & 0.008 & & & 1 & & & 0.164 \\
\hline GOT & $\begin{array}{c}27.2(18.2) \\
{[15-152]}\end{array}$ & & & 0.385 & & & 0.660 & & & 0.744 & & & 0.647 & & & 0.609 \\
\hline GGT & $\begin{array}{c}24.1(23.6) \\
{[7-156]}\end{array}$ & $\begin{array}{c}20.8 \\
(24.2) \\
{[7-156]}\end{array}$ & $\begin{array}{c}29.3(22.1) \\
{[9-95]}\end{array}$ & 0.030 & $\begin{array}{c}26.9(26.1) \\
{[9-156]}\end{array}$ & $\begin{array}{c}14.6(5.1) \\
{[7-26]}\end{array}$ & 0.019 & & & 0.102 & & & 1 & & & 0.483 \\
\hline$L D H$ & $\begin{array}{c}195.2(51.9) \\
{[106-363]}\end{array}$ & & & 0.634 & & & 0.924 & & & 0.766 & & & 0.753 & & & 0.593 \\
\hline$C R P$ & $\begin{array}{c}0.29(0.5) \\
{[0.02-3.56]}\end{array}$ & & & 0.209 & & & 0.459 & & & 0.271 & & & 0.224 & & & 0.060 \\
\hline Ferritin & $\begin{array}{c}99(105.4) \\
{[10.7-553.9]}\end{array}$ & & & 0.449 & & & 0.146 & & & 0.198 & & & 0.051 & & & 0.433 \\
\hline Vitamin D & $\begin{array}{c}67.7(26.9) \\
{[17.9-172.1]}\end{array}$ & & & 0.466 & & & 0.570 & $\begin{array}{c}63.8(22) \\
{[17.9-104.8]}\end{array}$ & $\begin{array}{l}94.4(42.7) \\
{[48.7-172]}\end{array}$ & 0.036 & & & 0.267 & & & 0.683 \\
\hline Leucocites & $\begin{array}{c}7149.1 \\
(2619.7) \\
{[2500-16300]}\end{array}$ & & & 0.634 & & & 0.932 & & & 0.803 & & & 0.651 & & & 0.691 \\
\hline Linfocites & $\begin{array}{c}2705.1 \\
(1474.5) \\
{[900-11399]}\end{array}$ & & & 0.530 & & & 0.243 & & & 0.779 & & & 0.788 & & & 0.609 \\
\hline Platelets & $\begin{array}{c}258051 \\
(76546) \\
{[133000-} \\
448000]\end{array}$ & & & 0.155 & & & 0.301 & & & 0.527 & & & 0.590 & & & 0.830 \\
\hline D Dimer & $\begin{array}{c}01.4(443.9) \\
{[80-3066]}\end{array}$ & & & 0.207 & & & 0.050 & & & 0.970 & $\begin{array}{c}381 \\
(452.8) \\
{[80-3066]}\end{array}$ & $\begin{array}{c}605.2 \\
(304.1) \\
{[266-951]}\end{array}$ & 0.026 & & & 0.113 \\
\hline $\begin{array}{l}\text { Herpes } \\
\text { Virus } 6\end{array}$ & & & & 0.748 & & & 0.310 & & & 0.916 & & & 0.490 & & & 0.388 \\
\hline $\begin{array}{c}\text { Parvovirus } \\
\text { B19 }\end{array}$ & & & & 0.070 & & & 0.193 & & & 0.734 & & & 0.091 & & & 0.130 \\
\hline $\begin{array}{l}\text { Lupus } \\
\text { anticoagulant } \\
\text { positive }\end{array}$ & & & & 0.725 & & & 0.464 & & & 0.107 & & & 0.641 & & & 0.673 \\
\hline
\end{tabular}


Patients with the pseudo-chilblain pattern were significantly younger (13.9 vs. 20.9 years; $p<0.001$; OR 0.01; CI95\% 0.87-0.98), and 69.2\% were barefoot at home ( $p<0.001$; OR $0.62 ; \mathrm{CI} 95 \% 0.27-8.71)$. These patients showed a trend towards a negative COVID-19 test result (11 vs. 2; OR 0.09; CI95\% 0.35-1.31), and had lower levels of glucose (82 vs. $93 \mathrm{~g} / \mathrm{L}$; $p<0.001)$ and GGT (14.6 vs. $26.9 \mathrm{U} / \mathrm{L} ; p=0.01)$ (Nagelkerke $\mathrm{R}^{2}=0.452$; Hosmer-Lemeshow test, $p=0.435)$.

The livedo pattern was correlated with being a smoker $(p=0.03)$ and having a negative COVID-19 test $(p=0.035)$, although they were not predictive factors (OR 0.11; CI95\% 0.64-55.66) and (OR 0.99; CI95\% 0-13.54), respectively (Nagelkerke $\mathrm{R}^{2}=0.306$; HosmerLemeshow test, $p=1.000)$.

In patients with vesicular eruption, vitamin D levels were significantly higher (94.4 vs. $63.8 \mathrm{nmol} / \mathrm{L} ; \mathrm{p}=0.03)$ and pruritus was more frequent (7 vs. 1 patient; $p=0.02)$ (OR 0.04; CI95\% 1.00-1.10) (Nagelkerke $\mathrm{R}^{2}=0.267$; Hosmer-Lemeshow test, $p=0.180$ ). D-dimer levels were correlated with urticarial eruption (605.2 vs. $38 \mathrm{ng} / \mathrm{mL}, p=0.02)$, but did not constitute a predictive factor (OR 0.30; CI95\% 0.99-1.00) (Nagelkerke $\mathrm{R}^{2}=0.034$; Hosmer-Lemeshow test, $p=0.664$ ).

\section{Discussion}

Knowledge about the cutaneous manifestations of COVID-19 is rapidly growing and has shown that many such signs can be of diagnostic and/or prognostic utility [2,4]. In fact, there are several reports warning about the appearance of similar skin manifestations in relation to COVID-19 vaccination [5]. Our study shows that although the maculopapular pattern was the most frequent COVID-19-associated pattern in our cohort, the types of lesions observed varied depending on the wave of infection, sex, age, and certain behavioral factors such as walking barefoot at home. Insufficient levels of vitamin D were associated with all cutaneous patterns except the vesicular pattern, whereas the highest D-dimer levels were observed in patients with urticaria. Finally, herpesvirus 6 IgM serology was found in 12 patients, accounting for $19 \%$ of the cohort.

The proportions and characteristics of the COVID-19-associated cutaneous manifestations in our cohort were similar to those previously described in the literature. Comparison with the findings of the Galvan et al. [1]. study reveals differences only in the case of urticarial eruption, which was recorded in $9.5 \%$ of our cohort versus $19 \%$ in that reported by Galvan et al. This discrepancy may be due to the fact that we did not attend patients in the emergency department, and recurrent urticaria and cases that are non-responsive to steroids are infrequent [6].

The age distribution was similar to that reported in other studies, and most patients presented a benign disease course. The pseudo-chilblain pattern was observed predominantly in younger patients (mean age, 13.9 years), while the remaining cutaneous manifestations were more evenly distributed. In our study, the mean (SD) age of patients with the livedo pattern was lower than that reported by Galvan and coworkers 29.1 (11.6) and 63.1 (17.3) years, respectively), and these patients had a benign course in contrast to that described by Piccolo et al. [7]. This may be due to selection bias: most patients who came to our clinic were outpatients, in contrast to the majority of other series, which consisted of hospitalized patients [2].

Only $42.9 \%$ of patients with cutaneous lesions in our cohort had a positive test of SARS-CoV-2, in line with the finding of Galvan et al. [1], whose study was conducted in similar conditions. The fact that COVID-19 tests were limited at the beginning of the pandemic likely contributed to the low percentage of confirmed cases, which subsequently increased with greater test availability.

In patients with maculopapular rash, an adverse reaction to medications prescribed for COVID-19 should be ruled out. In our cohort, 3 patients had suspected toxicoderma. In their sub-analysis of the COVID-Piel study, Català et al. reported that $78 \%$ of cases of maculopapular eruption in COVID-19 patients were associated with a history of drug use, mainly hydroxychloroquine, lopinavir/ritonavir, tocilizumab and azithromycin [8]. 
However, other series of cases of maculopapular rash in COVID-19 patients without a history of drug intake have also been reported [9].

The variation in the frequency of the different types of skin lesions observed over the successive waves may depend on several factors. The wide use of oral corticosteroids, not only in severe cases but also in patients with asymptomatic or mild disease [10], in addition to a decrease in the use of antimalarial and antiretroviral treatments, may contribute to a decrease in the incidence of dermatological diseases in these patients. The diagnosis of pseudo-chilblains was higher in the first wave than in the subsequent waves and was also more frequent in younger patients. This finding is in agreement with previous studies reporting an increase in cases in adults over successive waves, and in some cases, in more severe or recurrent infections [11]. Perniosis-type skin lesions or "COVID toes" are probably the most studied skin manifestations associated with COVID-19 to date and also the most controversial: in the majority of patients, SARS-CoV-2 infection could not be demonstrated, as also occurred in our cohort (15.3\% positive) [12]. Some findings suggest that these lesions are a consequence of a type I interferonopathy induced by the virus $[13,14]$, although recent publications support the lack of association between these chilblains and SARS-CoV-2 infection [15].

In our series, perniosis-like lesions were more frequent in the first wave and in children. Interestingly, we found that walking barefoot at home was significantly associated with this type of lesion, whereas no such association was observed for other patterns, such as maculopapular rash. These data support the view that lifestyle changes induced by lockdown may trigger and perpetuate the inflammatory response, as occurs in patients with type I interferonopathies [11], especially considering the improvements observed in these patients and the decrease in the incidence of perniosis like lesions after the lifting of the lockdown [16].

Laboratory tests showed that vitamin D levels were insufficient in most patients. However, we found no significant association between this parameter and the severity of cutaneous or general clinical signs of COVID-19. Interestingly, a significant association with vitamin $\mathrm{D}$ levels was observed only for the vesicular pattern, and these patients had vitamin D levels within the normal range. No association with previous sun exposure was observed. No studies have reported an association between vitamin D levels and any of the cutaneous manifestations included in the present study, whereas several have described an association between COVID-19 severity and vitamin D deficiency [17]. It is worth highlighting the relationship between the urticarial pattern and elevated D-dimer levels, which is considered a biomarker of disease activity and treatment response in spontaneous chronic urticaria [18].

The link between positive serology for HHV-6 and different clinical patterns in our cohort is particularly interesting and has been previously reported by our group [19]. The herpes simplex family of viruses has been implicated in both varicelliform rash [20] and pityriasis rosea-like eruptions [1,21]. In fact, several studies have reported an increase in the frequency of pityriasis rosea over the course of the pandemic [22,23] and described reactivation of the HHV-6 in cases of SARS-CoV-2 infection [24], as well as co-reactivation of HSV-1 and VZV in a patient with severe COVID-19 [25]. While it is difficult to establish an etiological association between HHV-6 infection and skin disease based on serological data alone, a growing body of evidence indicates that SARS-CoV-2 and even its vaccines [26] can reactivate other viruses [5].

The main limitation of our study is the small sample size, which was due to a gradual decrease in the number of patients referred to our clinic. This may reflect a real decrease in the incidence of COVID-19-associated cutaneous lesions, a decrease in consultations by affected patients, or an increase in knowledge by other non-dermatologists specialists about cutaneous manifestations. The other major limitation is the lack of microbiological confirmations in some of the cases, especially at the beginning of the pandemic, so we believe that it is possible that the percentage of positives would have been higher. 
In conclusion, although the maculopapular pattern is the cutaneous manifestation most frequently associated with SARS-CoV-2, skin lesions vary depending on sex, age, the specific wave of the pandemic, and certain behavioral factors, such as walking barefoot at home. Further research is required to fully elucidate the role of vitamin D in the different cutaneous lesions and the relevance of the association between high D-dimer levels and the urticarial pattern. Finally, the differential diagnosis of cutaneous lesions associated with COVID-19 should include the effects of COVID-19 therapies and the reactivation of other viruses.

Supplementary Materials: The following supporting information can be downloaded at: https: / / www.mdpi.com/article/10.3390/jcm11030600/s1, Figure S1: Questionnaires (initial consultation and after 4 weeks of follow-up); Table S1: Evolution of the incidence of cutaneous lesions associated with COVID-19 over the 4 waves of the pandemic.

Author Contributions: Conceptualization, A.N.-B., I.A.-G., A.M.M.-C., C.S.-E., M.P.-E., L.R. and Y.G.; methodology, A.N.-B., I.A.-G., A.M.M.-C., C.S.-E., M.P.-E., L.R. and Y.G.; software, I.A.-G.; validation, A.N.-B., I.A.-G., A.M.M.-C., C.S.-E., M.P.-E., L.R. and Y.G.; formal analysis, A.N.-B. and Y.G.; investigation, A.N.-B., I.A.-G., A.M.M.-C. and Y.G.; resources A.N.-B., I.A.-G., L.R. and Y.G.; data curation, A.N.-B., I.A.-G., A.M.M.-C. and Y.G.; writing-original draft preparation, A.N.-B., I.A.-G. and Y.G.; writing-review and editing, Y.G.; visualization, A.N.-B., I.A.-G. and Y.G.; supervision, A.N.-B., I.A.-G., A.M.M.-C. and Y.G.; project administration, I.A.-G., C.S.-E., M.P.-E. and Y.G.; funding acquisition, A.N.-B. and I.A.-G. All authors have read and agreed to the published version of the manuscript.

Funding: This research received no external funding.

Institutional Review Board Statement: The study was conducted in accordance with the Declaration of Helsinki, and approved by the Institutional Review Board (or Ethics Committee) of CEIC Aragón (approval C.I.PI20/323, 24 April 2020).

Informed Consent Statement: Informed consent was obtained from all subjects involved in the study.

Data Availability Statement: The data presented in this study are available on request from the corresponding author.

Acknowledgments: The authors thank Almirall S.A. for financial assistance in acquiring the instruments used in consultations.

Conflicts of Interest: The authors declare no conflict of interest.

\section{References}

1. Galván Casas, C.; Català, A.; Carretero Hernández, G.; Rodríguez-Jiménez, P.; Fernández-Nieto, D.; Rodríguez-Villa Lario, A.; Navarro Fernández, I.; Ruiz-Villaverde, R.; Falkenhain-López, D.; Llamas Velasco, M.; et al. Classification of the Cutaneous Manifestations of COVID-19: A Rapid Prospective Nationwide Consensus Study in Spain with 375 Cases. Br. J. Dermatol. 2020, 183, 71-77. [CrossRef] [PubMed]

2. González, F.G.; Correa, C.C.; Contreras, E.P. Manifestaciones cutáneas en pacientes con COVID-19: Características clínicas y mecanismos fisiopatológicos postulados. Actas Dermosifiliogr. 2020, 112, 314-323. (In Spanish) [CrossRef] [PubMed]

3. Rossi, A.; Magri, F.; Sernicola, A.; Michelini, S.; Caro, G.; Muscianese, M.; Di Fraia, M.; Chello, C.; Fortuna, M.C.; Grieco, T. Telogen Effluvium after SARS-CoV-2 Infection: A Series of Cases and Possible Pathogenetic Mechanisms. Ski. Appendage Disord. 2021, 7, 377-381. [CrossRef] [PubMed]

4. Sodeifian, F.; Mushtaq, S.; Rezaei, N. Manifestaciones cutáneas de la COVID-19: ¿Qué hemos aprendido tras un año de pandemia? Actas Dermosifiliogr. 2021. (In Spanish) [CrossRef] [PubMed]

5. Grieco, T.; Maddalena, P.; Sernicola, A.; Muharremi, R.; Basili, S.; Alvaro, D.; Cangemi, R.; Rossi, A.; Pellacani, G. Cutaneous adverse reactions after COVID -19 vaccines in a cohort of 2740 Italian subjects: An observational study. Dermatol. Ther. 2021, 34, e15153. [CrossRef] [PubMed]

6. Abuelgasim, E.; Dona, A.C.M.; Sondh, R.S.; Harky, A. Management of urticaria in COVID -19 patients: A systematic review. Dermatol. Ther. 2021, 34, e14328. [CrossRef] [PubMed]

7. Piccolo, V.; Neri, I.; Filippeschi, C.; Oranges, T.; Argenziano, G.; Battarra, V.C.; Berti, S.; Manunza, F.; Fortina, A.B.; Di Lernia, V.; et al. Chilblain-like lesions during COVID-19 epidemic: A preliminary study on 63 patients. J. Eur. Acad. Dermatol. Venereol. 2020, 34, e291-e293. [CrossRef] 
8. Català, A.; Galván-Casas, C.; Carretero-Hernández, G.; Rodríguez-Jiménez, P.; Fernández-Nieto, D.; Rodríguez-Villa, A.; Navarro-Fernandez, I.; Ruiz-Villaverde, R.; Falkenhain-López, D.; Llamas-Velasco, M.; et al. Maculopapular eruptions associated to COVID -19: A subanalysis of the COVID-Piel study. Dermatol. Ther. 2020, 33, e14170. [CrossRef]

9. Reymundo, A.; Fernáldez-Bernáldez, A.; Reolid, A.; Butrón, B.; Fernández-Rico, P.; Muñoz-Hernández, P.; De Argila, D.; Wiesner, T.; Llamas-Velasco, M. Clinical and histological characterization of late appearance maculopapular eruptions in association with the coronavirus disease 2019. A case series of seven patients. J. Eur. Acad. Dermatol. Venereol. 2020, 34, e755-e757. [CrossRef]

10. Wagner, C.; Griesel, M.; Mikolajewska, A.; Mueller, A.; Nothacker, M.; Kley, K.; Metzendorf, M.-I.; Fischer, A.-L.; Kopp, M.; Stegemann, M.; et al. Systemic corticosteroids for the treatment of COVID-19. Cochrane Database Syst. Rev. 2021, 2021, CD014963. [CrossRef]

11. Freeman, E.; McMahon, D.; Lipoff, J.; Rosenbach, M.; Desai, S.; Fassett, M.; French, L.; Lim, H.; Hruza, G.; Fox, L. Cold and COVID: Recurrent pernio during the COVID-19 pandemic. Br. J. Dermatol. 2021, 185, 214-216. [CrossRef]

12. Le Cleach, L.; Dousset, L.; Assier, H.; Fourati, S.; Barbarot, S.; Boulard, C.; Quetier, C.B.; Cambon, L.; Cazanave, C.; Colin, A.; et al. Most chilblains observed during the COVID-19 outbreak occur in patients who are negative for COVID-19 on polymerase chain reaction and serology testing. Br. J. Dermatol. 2020, 183, 866-874. [CrossRef]

13. Hubiche, T.; Cardot-Leccia, N.; Le Duff, F.; Seitz-Polski, B.; Giordana, P.; Chiaverini, C.; Giordanengo, V.; Gonfrier, G.; Raimondi, V.; Bausset, O.; et al. Clinical, Laboratory, and Interferon-Alpha Response Characteristics of Patients with Chilblain-like Lesions During the COVID-19 Pandemic. JAMA Dermatol. 2021, 157, 202-206. [CrossRef]

14. Sun, Q.; Freeman, E.E. Chilblains and COVID-19-An Update on the Complexities of Interpreting Antibody Test Results, the Role of Interferon $\alpha$, and COVID-19 Vaccines. JAMA Dermatol. 2021. [CrossRef]

15. Hébert, V.; Duval-Modeste, A.-B.; Joly, P.; Lemée, V.; Cellier, L.; Jouen, F.; Veber, B.; Drouot, L.; Boyer, O. Lack of association between chilblains outbreak and severe acute respiratory syndrome coronavirus 2: Histologic and serologic findings from a new immunoassay. J. Am. Acad. Dermatol. 2020, 83, 1434-1436. [CrossRef]

16. Baeck, M.; Herman, A. COVID toes: Where do we stand with the current evidence? Int. J. Infect. Dis. 2020, 102, 53-55. [CrossRef]

17. Mercola, J.; Grant, W.B.; Wagner, C.L. Evidence Regarding Vitamin D and Risk of COVID-19 and Its Severity. Nutrients 2020, 12, 3361. [CrossRef]

18. Ghazanfar, M.N.; Thomsen, S.F. D-dimer as a potential blood biomarker for disease activity and treatment response in chronic urticaria: A focused review. Eur. J. Dermatol. 2018, 28, 731-735.

19. Abadías-Granado, I.; Navarro-Bielsa, A.; Morales-Callaghan, A.; Roc, L.; Suso-Estívalez, C.; Povar-Echeverría, M.; Gilaberte, Y. COVID-19-associated cutaneous manifestations: Does human herpesvirus 6 play an aetiological role? Br. J. Dermatol. 2021, 184, 1187-1190. [CrossRef]

20. Lopez-Trujillo, E.; Mercader, S.R.; Güerri-Fernández, R.; Aldea, I.A.; Pujol, R.M.; Martin-Ezquerra, G. Varicella complicated with pneumonia in a patient infected by COVID-19: The need to rule out other viral coinfections in SARS-CoV-2 patients with vesicular eruptions. Int. J. Dermatol. 2021, 60, 886-888. [CrossRef]

21. Dursun, R.; Temiz, S.A. The clinics of HHV -6 infection in COVID -19 pandemic: Pityriasis rosea and Kawasaki disease. Dermatol. Ther. 2020, 33, e13730. [CrossRef]

22. Kutlu, Ö.; Metin, A. Relative changes in the pattern of diseases presenting in dermatology outpatient clinic in the era of the COVID -19 pandemic. Dermatol. Ther. 2020, 33, e14096. [CrossRef]

23. Xu, R.; Zhou, Y.; Cai, L.; Wang, L.; Han, J.; Yang, X.; Chen, J.; Ma, C.; Shen, L. Co-reactivation of the human herpesvirus alpha subfamily (herpes simplex virus-1 and varicella zoster virus) in a critically ill patient with COVID-19. Br. J. Dermatol. 2020, 183, 1145-1147. [CrossRef]

24. Drago, F.; Ciccarese, G.; Rebora, A.; Parodi, A. Human herpesvirus-6, -7, and Epstein-Barr virus reactivation in pityriasis rosea during COVID-19. J. Med. Virol. 2020, 93, 1850-1851. [CrossRef]

25. Català, A.; Muñoz-Santos, C.; Galván-Casas, C.; Roncero Riesco, M.; Revilla Nebreda, D.; Solá-Truyols, A.; Giavedoni, P.; Llamas-Velasco, M.; González-Cruz, C.; Cubiró, X.; et al. Cutaneous reactions after SARS-COV-2 vaccination: A cross-sectional Spanish nationwide study of 405 cases. Br. J. Derm. 2022, 186, 142-152. [CrossRef]

26. Diez-Domingo, J.; Parikh, R.; Bhavsar, A.B.; Cisneros, E.; McCormick, N.; Lecrenier, N. Can COVID-19 Increase the Risk of Herpes Zoster? A Narrative Review. Dermatol. Ther. 2021, 11, 1119-1126. [CrossRef] 